\title{
The Future Trend Natural Preservatives in the Food System: Essential Oils
}

\author{
Gulden Goksen ${ }^{1}$, Pinar Gumus ${ }^{2 *}$ \\ 1* Tarsus University, Vocational School of Technical Sciences, Department of Food Technology, Mersin, Turkey, (ORCID: 0000-0002-5432-7936), \\ guldengoksen@tarsus.edu.tr \\ ${ }^{2}$ Kilis 7 Aralik University, Faculty of Healthy Sciences, Departmant of Nutrition and Dietetics, Kilis, Turkey, (ORCID: 0000-0003-4085-9859), \\ pinargumus@kilis.edu.tr
}

(1st International Conference on Applied Engineering and Natural Sciences ICAENS 2021, November 1-3, 2021)

(DOI: $10.31590 /$ ejosat.1004380)

ATIF/REFERENCE: Goksen, G. \& Gumus, P. (2021). The Future Trend Natural Preservatives in the Food System: Essential Oils. European Journal of Science and Technology, (28), 440-443.

\begin{abstract}
Essential oils mainly used in food industry for food preservation are a main source of many bioactive compounds, which have antioxidant property, antimicrobial activity and also flavoring agents. Natural preservatives used in food products are suitable to be used for food preservation in order to extend the shelf-life and maintain the quality of foods. In this preservative application, more alternative approaches is required in order to meet consumer demands, establish food quality and preserve food products from environmental factors and maintain safety of foods due to increasing consumer awareness for healthy food products. This study presents an overview of essential oils and use of essential oils in the preservation of food products and also the most recent researches on essential oils incorporate into the food system.
\end{abstract}

Keywords: Essential oil, Natural preservatives, Food system, Lipid oxidation, Shelf life

\section{Gıda Sisteminde Geleceğin Trendi Doğal Koruyucular: Esansiyel Yăg}

$\ddot{O} \mathbf{z}$

Temel olarak gıda endüstrisinde gıda muhafazası için kullanılan uçucu yağlar, antioksidan özelliği, antimikrobiyal aktivite ve ayrıca aroma verici ajanları olan birçok biyoaktif bileşiğin ana kaynağıdır. Gıda ürünlerinde kullanılan doğal koruyucular, gıdaların raf ömrünü uzatmak ve kalitesini korumak amacıyla gıda muhafazasında kullanılmaya uygundur. Bu koruyucu uygulamada, tüketici taleplerinin karşılanması, gıda kalitesinin oluşturulması ve gıda ürünlerinin çevresel faktörlerden korunması ve sağlılı gıda ürünlerine yönelik tüketici bilincinin artması nedeniyle gıdaların güvenliğinin sağlanması için daha alternatif yaklaşımlara ihtiyaç duyulmaktadır. Bu çalışma uçucu yağlar ve gıda ürünlerinin korunmasında uçucu yağların kullanımına ve ayrıca gıda sistemine dahil edilen uçucu yağlarla ilgili en son araştırmalara genel bir bakış sunmaktadır.

Anahtar Kelimeler: Esansiyel yağ, Doğal koruyucular, Gıda sistemi, Yağ oksidasyonu, Raf ömrü.

\footnotetext{
* Corresponding Author: pinargumus@kilis.edu.tr
} 


\section{Introduction}

The demands of most consumers for secure and natural food products are increasing day by day. Many foods involve barrier against microbial deterioration and oxidation process during their shelf-life. Essential oils as naturally occurring active ingredient can prevent the development of superficial food pathogens. They can be combined into packaging for incremental release during shipping and storage in order to prolong shelf life and maintain nutritional, quality and organoleptic properties $[1,2]$.

Essential oils produced by steam or hydro-distillation from aromatic plant materials such as flowers, buds, seeds, leaves, twigs, bark, herbs, wood, fruits and roots obtained by plants relation to angiospermic families, are volatile or semi-liquids and liquid aroma compounds [1, 3-6]. Expression, fermentation, effleurage or extraction, steam distillation and hydro-distillation are widely preferred for commercial production of essential oils. Freeze drying, rotary evaporation, steam distillation, hydrolyzation and Gas chromatography are used in these extraction process [7].

Essential oils used for many purposes are classified according their applications: perfumery, soap and cosmetic sector; food and beverages industry as flavoring agents and preservation supplements agro-industrial proposes; medical and alternative medico-therapeutically techniques [7,8]. Essential oils exhibit many bioactivities such as antimicrobial, antibacterial, insecticidal, anti-inflammatory, antifungal, anticancer, antidiabetic, antiulcerogenic and antianxiety activities. They also have antioxidant activity however essential oils have lower antioxidants compared to commercial antioxidants [9-11].

Food packaging is aimed to defend food from extrinsic factors like temperature, moisture and light. Packages also preserve its content from other ambient factors such as odors, microorganisms, shocks, dust, vibrations and pressure forces [1]. Essential oils can be integrated into packaging, they can be alter the matrix of packaging compounds. Essential oils are volatile, moisture, light, heat-sensitive, oxygen and well-preserved by encapsulation $[8,9,12]$.

Food degradation is generally reasoned due to the oxidation period. It occurs during the processing and storage of food products and influences organoleptic and quality attributes. For example, a decrease in nutritional quality and the formation of rancid odours and flavours, toxic compounds, discolouration, changes in texture. It is necessary to inhibit oxidation by using natural antioxidants in food packaging which will result in an increment of consumer satisfaction $[13,14]$. This study focused on essential oils and use of essential oils in the preservation of food products and also the most recent researches on essential oils incorporate into the food system.

\section{The Preservation Potential of EOs in Food Systems}

During recent decades, there has been fruitful investigation on the use of essential oils in the preservation of food products in order to extend shelf life. Many researchers have utilized essential oils in order to are either included as food ingredients or to packaging, to prolong the shelf-life of food products [15, $16,17]$.

Essential oils as food preservatives with antibacterial and antioxidant properties get an acceptable utilization clinical utility for people and animals. A number of EOs and their principal components have been investigated using various toxicity testing, such as acute oral, dermal, and inhalation, primary eye and dermal and dermal sensitization, for the determination of their safety threshold spectrum throughout the last several years $[15,18]$.

As a result, the European Commission (EC) and the United States Food and Drug Administration (FDA) classifies some EOs, their components, and mixtures as generally recognized as safe (GRAS), and they approve to be used as natural food preservatives and flavouring agents. According to FDA, pure essential oils such as sage, thyme, coriander, ginger, basil, cinnamon, nutmeg, oregano, are labelled as GRAS, all of them are deemed safe within the recommended daily limits. In addition, several EOs components such as carvacrol, carvone, eugenol, thymol, linalool, cinnamaldehyde, citral, limonene, and menthol are endorsed as eco-friendly food additives [19].

In the beginning, EOs select as food preservative agents obviously based on their compositions and properties. Karoui and Hassoun (2017) reported that $1 \%$ concentration of basil and rosemary EOs showed different activity. While basil EO had higher antimicrobial activity, rosemary EO was more antioxidant activity. So their effects are distinct on food one is inhibiting foodborne pathogens the other is preventing rancidity [20].

The use of EOs as food preservatives should involve detailed information on the impact of food matrix components on EO antibacterial activities. EOs can interact with main food ingredients such as fat, protein, carbohydrate, and as a result, the effectiveness of EOs can be changed. Furthermore, some external factors like processing, packaging, temperature, humidity, microorganisms' varieties, and microbial load affect their activity $[21,22]$. Previous research reported that while EOs actions decrease against microorganisms the presence of a high amount of fat and protein content in the food matrix, also increases at the acidic food [19].

Food products, particularly meat and dairy products are sensitive to oxidization because of their composition. During the storage of these products, these reactions cause degradation and the formation of unpleasant chemicals and tastes, and odours. Because of the undesirable sensory qualities and health problems, customers may reject to consume rancidity products. In this way, the usage of essential oils may help to prevent lipid oxidation [23]. Mohamed and Mansour (2012) demonstrated that rosemary and marjoram EOs showed to be effective against lipid oxidation into frozen beef patties and during sensory evaluation, panellists give more scores to EOs incorporation patties [24].

Fratianni et al. (2010) evaluated the effect of the addition of thyme essential oils into in fresh chicken breast meat during storage of 3 weeks at $4{ }^{\circ} \mathrm{C}$. Thyme was exhibited to decline the lipid peroxidation, avoid the deterioration of protein, and prolonged the shelf-life of the chicken breast [25]. In melon, apple and pear juices, lemongrass EO, geraniol and cinnamon were effective to inactivate Salmonella Enteritidis, E. coli, and L. innocua [26]. When essential oils are applied to cheese, they indicate an antibacterial effect. Cheese has been recognized as one of the most widely consumed foods in the world, yet it is 
particularly susceptible to contamination by a variety of pathogenic spoilage bacteria, which could reduce its shelf life and present significant health risks to customers [27].

The cumin, rosemary and thyme EOs effect on physicochemical, microbial, rheological and sensorial attributes of soft cheese was obtained. According to the data, preventing the growth of E. coli, S. typhi, S. aureus, B. subtilis, B. cereus and $A$. niger on cheese. Thus, essential oils supplied an extension of shelf life and improvement for consumer perception [28]. Singh, Kapoor, and Singh (2011) established that the spoilage caused by bacteria was well controlled when anise EO and its oleoresin were added with yogurt at varying concentrations $(0.1-1.0 \mathrm{~g} / \mathrm{L})$ [29].

\section{Conclusions and Recommendations}

This review paper has exhibited the most recent researches on essential oils incorporate into the food system. The interest in natural ingredients against bacterial spoilage and lipid oxidation has increased as consumer preference for clean label and chemical-free alternatives has grown. Essential oils as natural additives, antibacterial, and antioxidant agents recognized as GRAS have received considerable attention. The successful protection application in food systems could be made possible by encapsulating essential oils without the effects on organoleptic properties of food. Before authorization for its utilization as natural preservatives in food industries, there is more clinical research need to verify the acute or chronic effects.

\section{References}

[1] Ribeiro-Santos, R., Andrade, M., de Melo, N. R., \& Sanches-Silva, A. (2017). Use of essential oils in active food packaging: Recent advances and future trends. Trends in food science \& technology, 61, 132-140.

[2] Ataei, S., Azari, P., Hassan, A., Pingguan-Murphy, B., Yahya, R., \& Muhamad, F. (2020). Essential oils-loaded electrospun biopolymers: A future perspective for active food packaging. Advances in Polymer Technology, 2020.

[3] Hamid, A. A., Aiyelaagbe, O. O., \& Usman, L. A. (2011). Essential oils: its medicinal and pharmacological uses. International journal of Current research, 33(2), 86-98.

[4] Saad, N. Y., Muller, C. D., \& Lobstein, A. (2013). Major bioactivities and mechanism of action of essential oils and their components. Flavour and Fragrance Journal, 28(5), 269-279.

[5] Solgi, M., \& Ghorbanpour, M. (2014). Application of essential oils and their biological effects on extending the shelf-life and quality of horticultural crops. Trakia Journal of Sciences, 12(2), 198-210.

[6] El Asbahani, A., Miladi, K., Badri, W., Sala, M., Addi, E. A., Casabianca, H., ... \& Elaissari, A. (2015). Essential oils: From extraction to encapsulation. International journal of pharmaceutics, 483(1-2), 220-243.

[7] Herman, R. A., Ayepa, E., Shittu, S., Fometu, S. S., \& Wang, J. (2019). Essential oils and their applications-a mini review. Adv Nutr Food Sci, 4(4), 1-13.

[8] Vintilă, I. (2017). Basic structure, nomenclature, classification and properties of organic compounds of essential oil. Essential Oils in Food Processing: Chemistry, Safety and Applications, 173-190.
[9] Morsy, N. F. S. (2017). Chemical structure, quality indices and bioactivity of essential oil constituents. Act. Ingred. Aromat. Med. Plants, 175-206.

[10]Setyaningsih, D., \& Siahaan, D. G. (2018, December). The Influence of Essential Oil Addition to Oxidative Stability of Palmoil Biodisel. In IOP Conference Series: Earth and Environmental Science (Vol. 209, No. 1, p. 012007). IOP Publishing.

[11]Kumar, A., Singh, P., Gupta, V., \& Prakash, B. (2020). Application of nanotechnology to boost the functional and preservative properties of essential oils. In Functional and Preservative Properties of Phytochemicals (pp. 241-267). Academic Press.

[12]Tongnuanchan, P., \& Benjakul, S. (2014). Essential oils: extraction, bioactivities, and their uses for food preservation. Journal of food science, 79(7), R1231-R1249.

[13]Atarés, L., \& Chiralt, A. (2016). Essential oils as additives in biodegradable films and coatings for active food packaging. Trends in food science \& technology, 48, 51-62.

[14]Sharma, S., Barkauskaite, S., Jaiswal, A. K., \& Jaiswal, S. (2020). Essential oils as additives in active food packaging. Food Chemistry, 128403.

[15]Pandey, A. K., Kumar, P., Singh, P., Tripathi, N. N., \& Bajpai, V. K. (2017). Essential Oils: Sources of Antimicrobials and Food Preservatives. Frontiers in Microbiology, 7(2161).

[16]Prakash, B., Kedia, A., Mishra, P. K., \& Dubey, N. K. (2015). Plant essential oils as food preservatives to control moulds, mycotoxin contamination and oxidative deterioration of agri-food commodities - Potentials and challenges. Food Control, 47, 381-391

[17]Göksen, G., Fabra, M. J., Ekiz, H. I., \& López-Rubio, A. (2020). Phytochemical-loaded electrospun nanofibers as novel active edible films: Characterization and antibacterial efficiency in cheese slices. Food Control, 112, 107133.

[18]Prakash, B., Singh, P., Kedia, A., \& Dubey, N. K. (2012). Assessment of some essential oils as food preservatives based on antifungal, antiaflatoxin, antioxidant activities and in vivo efficacy in food system. Food Research International, 49(1), 201-208.

[19]Falleh, H., Ben Jemaa, M., Saada, M., \& Ksouri, R. (2020). Essential oils: A promising eco-friendly food preservative. Food Chemistry, 330, 127268.

[20]Karoui, R., \& Hassoun, A. (2017). Efficiency of rosemary and basil essential oils on the shelf-life extension of Atlantic mackerel (Scomber scombrus) fillets stored at 2 C. Journal of AOAC International, 100(2), 335-344.

[21]Calo, J. R., Crandall, P. G., O'Bryan, C. A., \& Ricke, S. C. (2015). Essential oils as antimicrobials in food systems-A review. Food Control, 54, 111-119.

[22]Rodriguez-Garcia, I., Silva-Espinoza, B., Ortega-Ramirez, L., Leyva, J., Siddiqui, M., Cruz-Valenzuela, M., . . . AyalaZavala, J. (2016). Oregano essential oil as an antimicrobial and antioxidant additive in food products. Critical Reviews in Food Science and Nutrition, 56(10), 1717-1727.

[23]Pateiro, M., Barba, F. J., Domínguez, R., Sant'Ana, A. S., Mousavi Khaneghah, A., Gavahian, M., . . . Lorenzo, J. M. (2018). Essential oils as natural additives to prevent oxidation reactions in meat and meat products: A review. Food Research International, 113, 156-166.

[24]Mohamed, H. M., \& Mansour, H. A. (2012). Incorporating essential oils of marjoram and rosemary in the formulation of beef patties manufactured with mechanically deboned 
poultry meat to improve the lipid stability and sensory attributes. LWT-Food Science and Technology, 45(1), 7987.

[25]Fratianni, F., De Martino, L., Melone, A., De Feo, V., Coppola, R., \& Nazzaro, F. (2010). Preservation of chicken breast meat treated with thyme and balm essential oils. Journal of Food Science, 75(8), M528-M535.

[26]Raybaudi-Massilia, R. M., Mosqueda-Melgar, J., \& MartinBelloso, O. (2006). Antimicrobial activity of essential oils on Salmonella enteritidis, Escherichia coli, and Listeria innocua in fruit juices. Journal of food protection, 69(7), 1579-1586.

[27]Mishra, A. P., Devkota, H. P., Nigam, M., Adetunji, C. O., Srivastava, N., Saklani, S., . . Mousavi Khaneghah, A. (2020). Combination of essential oils in dairy products: A review of their functions and potential benefits. LWT, 133, 110116.

[28]EL-Kholy, W., \& Aamer, R. (2017). Effect of Some Essential Oils on the Quality of UF-Soft Cheese During Storage. Alexandria Journal of Food Science and Technology, 14(1), 13-28.

[29]Singh, G., Kapoor, I. P. S., \& Singh, P. (2011). Effect of volatile oil and oleoresin of anise on the shelf life of yogurt. Journal of Food Processing and Preservation, 35(6), 778783. 